\title{
Speech-language assessment in a linguistically diverse setting: Preliminary exploration of the possible impact of informal 'solutions' within the South African context
}

\author{
J Barratt, K Khoza-Shangase, K Msimang \\ Department of Speech Pathology and Audiology, School of Human and Community Development, University of the Witwatersrand, Johannesburg \\ Joanne Barratt \\ Katijah Khoza-Shangase \\ Kwandinjabulo Msimang
}

Corresponding author: J Barratt (joanne.barratt@wits.ac.za)

\begin{abstract}
Speech-language therapists (SLTs) working in the context of cultural and linguistic diversity face considerable challenges in providing equitable services to all clients. This is complicated by the fact that the majority of SLTs in South Africa are English or Afrikaans speakers, while the majority of the population have a home language other than English/Afrikaans. Consequently, SLTs are often forced to call on untrained personnel to act as interpreters or translators, and to utilise informally translated materials in the assessment and management of clients with communication impairments. However, variations in translation have the potential to considerably alter intervention plans. This study explored whether the linguistic complexity conveyed in translation of the Western Aphasia Battery (WAB) test changed when translated from English to isiZulu by five different first-language IsiZulu speakers. A qualitative comparative research design was adopted and results were analysed using comparative data analysis. Results revealed notable differences in the translations, with most differences relating to vocabulary and semantics. This finding holds clinical implications for the use of informal translators as well as for the utilisation of translated material in the provision of speech-language therapy services in multilingual contexts. This study highlights the need for cautious use of translators and/or translated materials that are not appropriately and systematically adapted for local usage. Further recommendations include a call for intensified efforts in the transformation of the profession within the country, specifically by attracting greater numbers of students who are fluent in African languages.
\end{abstract}

Keywords: interpretation, linguistic diversity, speech-language therapy, translation, Western Aphasia Battery

S Afr J CD 2012;59(1):34-44. DOI:10.7196/SAJCD.51

The South African healthcare system is plagued with challenges, including but not limited to shortages of skills and equipment and staff retention difficulties. Over and above these, there is the challenge of providing an efficient and equitable service to patients from diverse cultural and linguistic backgrounds (Mosdell, Balchin \& Ameen, 2010). The issue of cultural and linguistic diversity poses considerable challenges in the provision of speech-language therapist (SLT) services since the majority of graduates are English or Afrikaans speakers with little or no knowledge of other official languages and/or cultural backgrounds of their patients (Gerber, 2009; Bornman, Sevcik, Romski \& Pae, 2010).

Although English is used as the language of instruction in the majority of schools, tertiary institutions, the work place, and in healthcare settings, $92 \%$ of the total South African population are reported to have a home language other than English (Statistics South Africa, 2003). IsiZulu, the language of investigation in the current study, is reported as the mother tongue of $23.8 \%$ of the South African population. Language rights of all South African citizens are firmly entrenched in, inter alia, sections 6, 29, 30 and 31 of the Constitution of the Republic of South Africa, Act 108 of 1996. Given the South African government's attempts to address language rights through changes in national policies, a higher emphasis needs to be placed on the development of culturally and linguistically suitable and reliable speech and language assessment tools (Khoza, Ramma, Mophosho \& Moroka, 2008; Bornman et al., 2010) with equal focus on the use of interpreters in SLT engagements. This need is substantiated by research which illustrates that cross-linguistic healthcare consultations have the potential to affect the efficacy and appropriateness of intervention (Swedley, Stith \& Nelson, 2003) as well as patient satisfaction (Foley, 2005).

Despite some preliminary attempts to translate assessment batteries into local languages (e.g. Mosdell et al., 2010), difficulties continue to be incurred as a result of the range of languages spoken in South
Africa. Consequently, one of the proposed 'solutions' to mitigating the negative effects of language barriers in cross-linguistic consultations has been to employ trained translators or interpreters to act as mediators. The differences between translation and interpretation may be subtle, yet may have far-reaching effects on the consultation. Spiggle (1994) states that translation refers to either written or verbal communication in the second language having the same meaning when written or spoken in the first language, while interpretation relates to a deduction of information, and may refer to assessing intentions and inferences, making sense of experience and behaviour, and seeing or understanding a phenomenon in one's own terms by grasping its essence (Spiggle, 1994). Many researchers prefer the use of the term adaptation as opposed to translation or interpretation as there is an acknowledgement that there is a requirement for adaptation in culture, content and wording, over and above the simple translation of a test (Geisinger, 1994). Davidson (2001) claims that interpretation is always contextual; however in institutional settings, such as hospitals, interpretation may be defined by social and behavioural norms. Davidson (2001) asserts that in the medical setting, clinicians usually judge the patients' physical and verbal signs for social and moral relevance in order to make a diagnosis, and the current authors argue that an untrained interpreter may not look for such cues during a mediated consultation. Moreover, in speechlanguage assessments, untrained interpreters may not be aware that subtle changes or inaccuracies in understanding or production can indicate an impairment that requires intervention. Adaptation of test materials compounds this issue to a further degree.

Despite the fact that South African legislation, as indicated by the Policy on Language Services (2011) for the Department of Health (Department of Health, 2011), promotes the use of interpreters in healthcare settings, few trained interpreters are available in the public healthcare sector (Penn, 2007). As a result, most therapists rely on untrained interpreters and translators during assessments and therapy sessions. In hospital 
settings, nurses, cleaners, general assistants, and family members are frequently called upon to translate or interpret for patients who do not speak and/or understand English. This observation is confirmed by Elderkin-Thompson, Silver and Waitzkin (2001), who report that bilingual individuals with no formal training as translators frequently translate for patients who are non-English speaking. Much meaningful information may be lost since the person translating may not have an understanding of terms used, may use the notion of direct translation or translate the message differently, thus creating confusion and changing the meaning of the item to be translated (Elderkin-Thompson et al., 2001). Previous research has also shown that ad hoc interpreters can commit many errors of interpretation such as omitting important information as a result of limited vocabulary during translation (Flores, Laws, Mayo, Zuckerman, Abreu, Medina \& Hardt, 2003). It can thus be anticipated that results obtained from mediated SLT assessments may be compromised, leading to incorrect diagnoses, particularly where untrained translators or interpreters are used. In speech-language therapy this challenge is more complex because how communication occurs is a crucial aspect, not just what is communicated as in most other healthcare setting scenarios.

Owing to the limited focused research on this challenge within the South African context, the ad hoc arrangements made during assessment and management of clients from linguistically and culturally diverse populations creates translation and adaptation difficulties which arguably influence the normative interpretation of assessment measures, and consequently management plans. Despite the availability of frameworks and guidelines for adapting or translating test measures (e.g. Geisinger, 1994), as well as published guidelines for working with interpreters, anecdotal evidence suggests that these are infrequently followed by SLTs in the South African context; this is believed to have a negative impact on speech-language therapy service provision as a whole.

One of the populations with whom SLTs commonly work is the neurologically impaired adult population. Van Schoor, van Niekerk and Grobbelaar (2001) reported that South Africa is rated among the highest in the world for casualty admission rates secondary to motor vehicle accidents. Global statistics reveal that South Africa has among the highest HIV/AIDS infection rates in the world, with an estimated 410000 new infections in 2010 (Statistics South Africa, 2010). Mochan, Modi and Modi (2003) show a relationship between HIV infection and cerebrovascular accidents as a result of vascular abnormalities, coagulation disorders and cardio-embolic disease. This high incidence of stroke concurs with the findings of the Southern Africa Stroke Prevalence Initiative (SASPI) Project Team (2004), who report an incidence of cerebrovascular accidents of 243 per 100000 people. As a result of the above-mentioned factors, it can be assumed that in South Africa the number of patients with speech, language and/or cognitivelinguistic impairments as a consequence of neurological impairment is high, resulting in an increased need for speech-language therapy assessment and intervention.

One commonly used formal English assessment tool for speechlanguage and cognitive-linguistic assessment of the neurologically impaired adult population is the Western Aphasia Battery (WAB) (Kertesz, 1982). This tool includes subtests relating to content, fluency, auditory comprehension, repetition, naming, reading, writing and calculation (Kertesz, 1982), and thus assesses areas of functioning in which patients with traumatic brain injuries also experience difficulty (Kennedy \& Yorkston, 2000).

Formal assessment measures provide a baseline for intervention, which may be compromised when a patient's first language is not English. This becomes abundantly clear in a multilingual context like South Africa where the majority of formal assessment measures available are written in English and standardised in different settings. As a result, ad hoc translators are often used in clinical encounters, and this may influence the assessment findings in a number of ways. The untrained individual's lack of familiarity with the speech materials presented and compromised competence with the language that the clinician speaks may influence the accuracy of translation. Translators who are neither competent in English nor the language being translated may not perform as well as native speakers of that language. Hence, SLTs need to take cognisance of these factors and how their lack of knowledge of the native languages of their clients can negatively affect the accuracy of assessment results, preventing them from fully meeting their clients' needs. This heightened awareness should range from case history taking to the actual assessment to the test material used in the assessment, and therefore more emphasis should to be placed on development of assessment and intervention materials in all languages.

In response to this need within the South African SLT profession, the current study explored whether differences existed in the translation of the WAB by five first-language isiZulu speakers. In a multilingual context, it is well documented that many of the formal speech-language assessments are inappropriate for first-language English speakers, and indeed speakers of other languages. It is therefore crucial for all avenues to be explored in order to appropriately adapt or develop the most accurate and efficient assessment tools for the African continent.

\section{Methodology}

Prior to the study being conducted, permission was obtained from the University of the Witwatersrand Non-Medical Ethics Committee (Protocol number: H090404).

\section{Aim}

To determine whether the linguistic complexity of the test items of the WAB changed when translated from English to isiZulu.

\section{Objective}

To determine whether differences existed in the translation of the WAB from English to isiZulu when translated by five first-language isiZulu speakers.

\section{Research design}

A comparative qualitative research design was employed in order to determine whether similarities and differences existed within the data rather than starting with predefined concepts (Ovretveit, 1998).

\section{Data collection}

The initial part of the study involved translating the WAB from English to isiZulu in order to investigate whether the syntax and semantics as well as item complexity and familiarity changed during translation. This translation was performed by the third author (KM - translator 1). Another translation was then performed by a senior lecturer from the Department of African Languages (ALL - translator 2). The two sets of translations were compared and one set was agreed upon for use as a baseline comparative set. For the purpose of this study, the translation made by KM was chosen to be the baseline for comparison. This choice was based on the fact that she had detailed knowledge on the test material being used for translation, as well as the purpose for which the assessment tool was established. Furthermore, while the translations made by both translator 1 and translator 2 were considered to be accurate, translator 1's choice of words was thought to be less academic/formal, and therefore more familiar to the participants. Once the WAB had been translated, the three subtests deemed by the researchers to comprise the most complex linguistic features were identified: the subtests of auditory verbal comprehension, sequential commands and spontaneous speech. These were then utilised in the second phase of the study where verbal translations were conducted with the five participants (Tables 2 - 4).

Data collection took place with each participant individually in a quiet private consulting room at the University Speech and Hearing Clinic. The researcher dictated each item of each of the subtests individually, and the participants were instructed to verbally translate these from English to isiZulu. These translations were digitally audio-recorded and later transcribed. 


\section{Participants}

Five first-language isiZulu speakers were recruited using convenience sampling. The choice of isiZulu speakers was based on the fact that this is the most widely spoken African language in South Africa (Stats SA, 2003), and represents the most commonly spoken African language at the University Speech and Hearing Clinic. Furthermore, both the second and third authors are first-language isiZulu speakers. Inclusion criteria stipulated that all participants needed to be over the age of 18 years, be first-language isiZulu speakers, and should consider themselves to be proficient in English as per self-report. Table 1 provides a description of the participants.

All participants were provided with information letters and consent forms in both English and isiZulu prior to the commencement of data collection. Where the participants were unable to read, the researcher verbally explained the study to them in isiZulu and verbal assent was accepted in lieu of written consent. Ethical considerations were guided by the principles of the South African Medical Research Council (South African Medical Research Council, 2003).

\section{Data analysis and trustworthiness of findings}

Data were analysed qualitatively using comparative analysis. Each translation was transcribed and back-translated from isiZulu to English. Thereafter, each translation was compared against the baseline translation. Furthermore the translations were compared with each other so as to identify differences in translation across the five participants. Trustworthiness of findings was accounted for by means of back-translation of the baseline WAB, as well as independent validity checks of two of the five participants' translations to eliminate bias.

\section{Results}

Results are presented in accordance with the aims of the study. Results of the translations of the most linguistically complex subtests of the WAB are depicted in Table 2 (Tables 2 - 4 are placed at the end of the article to facilitate the flow of the article).

\section{Comparison of translations made by the researcher and African Languages Lecturer (ALL)}

Initially, the translations made by the researcher and the ALL were compared. While some differences relating to sentence structure and vocabulary were noted, these appeared to be mainly dialectal in nature and did not affect the overall linguistic complexity of the test items. The reasons behind these differences appeared to pertain to the ALL's more formal and academic use of isiZulu, while the researcher's choice of words was more colloquial.

Within the subtest of auditory verbal comprehension, a few changes to structure and complexity of the questions were noted. An example of this can be seen in the translation of the question 'Is the door closed?' In English this phrase consists of the structure Copula Determiner Noun Adjective, whereas in isiZulu the structure changes to Adjective Noun which is translated to 'Uvaliwe umnyango?' Although the structure of the question changes, the meaning remains the same, and when translated back into English the question stays the same. Similarly, by translating the question 'Are you wearing red pyjamas?' to isiZulu ('Ugqoke izimpahla zokulala ezibomvu?') the sentence structure changes to 'Are you wearing pyjamas that are red?' This indicates that the meaning does not change, although the length of the question increases. This was also noted in the phrase, 'Do you eat a banana before you peel it?'('Uhluba ubhanana ngaphampi kokuba uwudle?'). In this phrase the Noun Phrase (NP) is followed by the Verb Phrase (VP) in English. However, in isiZulu the VP is followed by the NP, further indicating that the structure of the question changes, yet does not compromise the meaning of the question. When translated back to English, the phrase reads as 'Do you peel a banana before you eat it?'

In the subtest of spontaneous speech, differences were also noted. The researcher translated the phrase 'What is your occupation?' to 'Usebenza laphi?' which, when translated back into English means 'Where do you work?' This implies that the response obtained could refer to place of occupation but not the type of occupation.

Some differences were also noted in the translation of the auditory verbal comprehension subtest. For example, the researcher translated the command 'Shut your eyes' as 'Vala amehlo' whereas the ALL translated it as 'Chimeza'. Both of these translations are accurate representations of the English command as a patient would perform the command correctly if translated either way. The only important difference in the two translations is that the translation made by the researcher can be back-translated into English as 'Close your eyes' whereas the translation made by the ALL would be translated to English as 'Shut your eyes'. Another difference was noted in the command 'Point to the chair'. People from the more rural parts of KwaZulu-Natal and those who have formally studied isiZulu tend to use the word 'isihlalo' as used by the ALL, for 'chair'. However, the researcher translated the word 'chair' as 'isitulo'. The word 'isitulo' is a 'borrowed word' taken from the Afrikaans word 'stoel' and is used more commonly in more urban areas, whereas 'isihlalo' is the more authentic version of the word 'chair' in isiZulu.

In some instances, the word order of the sequential commands changed. An example of this is seen in the command 'Point to the comb with the pen', which was translated to 'Ngepeni, khomba ikama', meaning 'With the pen, point to the comb'. Although this change did not compromise the overall meaning of the command, it has the potential to affect a patient's understanding of the command and may also change the sequential order in which they carry out more complex commands.

Most of the changes that were noted from the initial translation of the WAB were concerned with structure and vocabulary. Since the ALL had studied isiZulu at both an undergraduate and postgraduate level, her translations were more formal as opposed to the more colloquial translations by the researcher. This implies that level of education may play an influential role on translation. These effects of education may also be true for the patient population. This is of significance to SLTs since the risk of misdiagnosis of communication impairments may

\section{Table 1. Personal characteristics of the participants}

\begin{tabular}{|c|c|c|c|c|c|c|}
\hline Participant & Age & Gender & Occupation & Highest level of education & Languages spoken & Place of origin/birth \\
\hline Translator 1 & 22 & Female & $\begin{array}{l}\text { Speech and hearing } \\
\text { therapist }\end{array}$ & $\begin{array}{l}\text { BA Speech and Hearing } \\
\text { Therapy }\end{array}$ & IsiZulu, English, Afrikaans & Newcastle \\
\hline Translator 2 & 38 & Female & Senior Lecturer & PhD (African Languages) & IsiZulu, English & Johannesburg \\
\hline 1 & 56 & Male & Gardener & Grade 11 & IsiZulu and English & Rural KwaZulu-Natal \\
\hline 2 & 52 & Female & Nursing Sister & Diploma in nursing & IsiZulu and English & Pietermaritzburg \\
\hline 3 & 23 & Female & Student & $\begin{array}{l}3 \text { years at university studying } \\
\text { Law }\end{array}$ & IsiZulu and English & Pietermaritzburg \\
\hline 4 & 38 & Female & Cleaner & Grade 9 & IsiZulu, English and Sotho & Newcastle \\
\hline 5 & 34 & Male & $\begin{array}{l}\text { Painter \& fixes air } \\
\text { conditioners }\end{array}$ & Grade 12 & IsiZulu, English and Sotho & Soweto \\
\hline
\end{tabular}


be increased by failure to ensure effective translation of assessment materials or by assessing the patient in a language that he/she does not understand (Stolk, Ziguras, Saunders, Garlick, Stuart \& Coffey, 1998). This suggests that SLTs should be cautious in their interpretation of assessment findings elicited through informally mediated consultations.

\section{Comparison of verbal translations made by the five participants}

The results of this aspect of the study have been tabulated in Table 2 . Based on these results, it was noted that many more discrepancies were noted across the translations, specifically those concerning vocabulary used, as well as sentence structure and semantics.

\section{Variations in translation relating to vocabulary}

As evident in Table 2, much of the vocabulary used in the subtest may be considered inappropriate for assessment in South Africa. This concurs with the findings of Mosdell et al. (2010), who also found that test items in the Boston Naming Test and the Cookie Theft Test were both linguistically and culturally biased, affecting the reliability of the tests when used in the South African context. Over and above the effect that culturally inappropriate vocabulary may have on the responses obtained from a patient, the nature of the vocabulary may be altered by the translator if he/she has limited vocabulary in his/her own language and/or in English. For example, when looking at nouns such as Smith, Brown, Windsor and Toronto, it may not be easy for a second-language speaker of English to relate to such words, and may thus affect the results of the testing procedure. Anderson (1992) recommends that materials used during assessments and therapy should be culturally and linguistically sensitive so as to appropriately guide patient management. Vocabulary such as 'hotel' and 'snow' in the WAB may be inappropriate to use in a country such as South Africa, especially in the government healthcare context, since many people in this context may not be familiar with the concept of a hotel. Similarly, many people in South Africa have never seen snow before or heard what it is called in languages other than their own. For this reason it may be difficult to comment on when it snows because of the fact that they do not have any experience on which to base this. The WAB was standardised in New York and therefore the expected response for the absurdity question 'Does it snow in July?' is 'no'. However, in South Africa it is quite possible to have snow in certain parts of the country at this time of year. This is therefore clinically relevant as a patient may then be thought to be presenting with impaired comprehension because of the fact that he answered the question incorrectly.

The word 'axe' is also considered inappropriate for use in a South African assessment battery. This is due to the fact that some patients may be unfamiliar with the name of this object and therefore may have difficulty in answering the question. For example, participant 4 translated 'Do you cut grass with an axe?' as 'Unganqamula utshani ngombese?' meaning 'Can you cut grass with a knife?' This may be due to the fact that she does not have the vocabulary to make a connection between the English word 'axe' and the isiZulu word 'imbazo'. Implications of this mistranslation which leads to changed meaning entirely are considerable and have direct impact on test scoring as well as eventual diagnosis.

\section{Errors in translation of syntax and/or semantics}

Word order is an aspect that may be altered during translation and may have negative effects on SLT assessments. Berndt (2001) states that verbal short-term memory is frequently affected in patients with neurological impairments. Therefore a change in sentence structure may have a negative effect on the neurologically impaired patient's ability to comprehend an instruction.

From the subtest of auditory verbal comprehension (Table 2), a number of semantic differences in translation were apparent. Participant 3 translated the question 'Are the lights on in this room?' as 'Are the lights on in this room or not?' Similarly, participant 3 changed the nature of the question 'Does March come before June?' to 'What comes first, March or June?' and translated 'Is a horse larger than a dog?' to 'What is larger, a dog or a horse?' In all of these instances, patients with neurological impairments may have difficulty in responding accurately since the nature of the question has been changed from one which requires a yes/ no response to a forced alternative, and the processing requirements being assessed have also been simplified. In the questions 'Are you a man or a woman?', 'Are you a doctor?' and 'Is this an assessment room?', participant 5 consistently asked the question by saying 'Could you/this be a woman/doctor/therapy room?' This increases the level of complexity of the question and requires a degree of reasoning in formulating an answer, which may be difficult for the neurologically impaired patient, or the patient's reasoning may be difficult for the SLT to follow. In the question 'Am I a man or a woman?' participants 1, 2, 3 and 4 all changed the nature of the semantics, thus posing the questions 'Is she the female here?', 'Am I a woman?', 'Is she a male or a female?' and 'Are you a man or a woman?' respectively. Another change in semantics can be seen in the question 'Will paper burn in a fire?' where participant 4 translated it to 'Is paper burning?', thereby altering the meaning conveyed in the question and the expected response. These examples not only reveal the impact on complexity of the stimuli, but also highlight the influence of informal translation on validity of the instrument.

The only semantic differences in the spontaneous speech subtest (Table 3) were in the question 'What is your occupation?' This may be because few people use the term 'occupation' when they speak about work, but tend to use the word 'job' or 'work', and may explain participant 2's translation to 'Where do you work?' which resulted in a change of semantics. In the same question, participant 4 mistook the meaning of the word 'occupation' for the meaning of 'address' in the question 'What is your occupation?', thereby completely altering the meaning of the question.

Analysis of the subtest of sequential commands (Table 4) revealed that in the command 'Point with the pen to the book' participants 2 and 3 changed the word order to 'Khomba ibuku ngepeni' and 'Khomba incwadi ngepeni' respectively, meaning 'Point to the book with the pen', thus changing the sequential nature of the command. Furthermore, participant 4 translated the same command to 'Khomba ikamu neball peni' meaning 'Point to the comb with the pen' thus changing the semantics of the command. Similarly, in the command 'Point to the window then to the door', participants 1 and 4 both translated the command as 'Point to the window and the door', and in the command 'Point to the pen and the book', participants 3 and 5 both translated the command to 'Point to the pen and then point to the book.' These errors in translation affect the expected sequential order of the response and consequently patients may be misdiagnosed as having auditory memory impairments and/or sequencing problems incorrectly. In the command 'Point to the comb with the pen', participants 1 and 4 translated this as 'Point with the pen to the comb' which, although it maintains the semantics of the command, changes the complexity. Similarly, the command 'With the book, point to the comb' yielded errors in translation, where participant 2 translated it as 'Point with the comb to the book', thus changing the semantics, and participant 4 translated it as 'On the book point to the book' thus providing a nonsensical command. The command 'Put the comb on the other side of the pen and turn over the book' was problematic for almost all of the participants because of the increasing complexity of the command, with only participant 5 giving an accurate translation of the command. An important factor highlighted by Berndt (2001) is that most neurologically impaired patients have impairments related to sentence comprehension tasks, especially with semantically reversible sentences that are syntactically complex. This implies that a patient who already presents with a neurological impairment may have marked difficulties in answering a question with complex semantics and syntax, especially where translation is necessary; where inaccurate translations are performed, the assessment process is therefore severely hampered.

\section{Discussion}

As illustrated in this preliminary study, numerous differences and errors in translation may occur when untrained translators are 
used, and these have the potential to alter the responses obtained from the patient. This may result in misdiagnosis and consequently inappropriate intervention. While it is also not possible to fully identify the characteristics that make one translator more accurate than another, there are a number of factors that can be identified from the current study. The following factors need consideration when translations are conducted from English to isiZulu:

\section{The impact of isiZulu as a tonal language on translation}

Stress and intonation patterns impact substantially on the semantics of spoken language in isiZulu. This implies that lexical tone can be used to attach different meanings to words which share the same phonemic content (Kuun, Zimu, Barnard \& Davel, 2005). The effects of this were noted, for example, during the transcription of participant 4's question 'Am I a man or a woman?' which was translated to 'Ungumuntu wesifazane noma wesilisa?' As a result of the intonation patterns of the language, stress can be placed in different places on the word 'ungumuntu' thereby changing the meaning of the sentence. The subtle difference between 'ungumuntu' (is she/he) and 'ungumuntu' (are you) will affect the patient's response. This is an important consideration since the ability to accurately detect intonation is a cognitive function involving the right hemisphere (Kuun et al., 2005); therefore it has significance in the assessment of a neurologically impaired individual.

\section{The impact of gender on translation}

Although the sample size was small, it was observed that generally the male participants translated the test items with the closest level of accuracy to the original stimuli. It is unclear why the males in this study consistently gave more accurate translations than the females; however, this finding is of interest given that in most clinical encounters, females are more likely to be requested to assist with translation when a language barrier exists. Within the South African context, females dominate the nursing profession, and they are also the ones who most often take the role of caregivers. This reality is also confirmed by Friedland and Penn (2003), who state that it is typical within the South African healthcare sector for nurses and cleaning staff, who are predominantly female, to act as translators in cross-linguistic encounters.

Interestingly, on a few occasions in the current study, female participants used the carrier phrase 'please' during translation of test items. For example, in the spontaneous speech subtest, both participants 2 and 3 translated 'Tell me a little about why you are here' to 'Please tell me a little about why you are here'. Similarly in the sequential command 'Raise your hands', participant 2 translated this to 'Please raise your hands'. While the sample is too small to draw definitive conclusions as to why this occurred, it is possible that the female participants, because of their 'nurturing' nature attempt to establish a rapport with the 'patient' during the process of informal translation. This use of the carrier phrase may also be related to cultural norms in isiZulu which may dictate subservience on the part of females in general societal functions and engagements.

\section{The impact of education on translation}

Based on the current findings, it was evident that level of education also appears to play a role in the type of translation. Participant 4 has the lowest level of education. A number of variations were noted in the translations made by this participant compared with the other translators, with the most significant variation being in the translation of 'What is your occupation?' Owing to the fact that participant 4 may not have had extensive exposure to formal English because of her level of education, she was unable to understand the term 'occupation', but instead interpreted it as 'address'. Ercikan (1998) states that a translation made by an interpreter must reflect not only the meaning of the original item, but should also maintain the same relevance, intrinsic interest and familiarity of the item content. Furthermore, Ercikan (1998) argues that if this is not done, what the item measures may be altered. The current authors agree with this statement as evidence from the current study provides some support for it.
A further example of the impact of education on translation can be seen in the subtest of auditory verbal comprehension, where participant 4 was unable to provide the correct term for the object 'axe', indicating that she did not have sufficient vocabulary to make the translation. However, having said this, the participant with the highest level of education did not always translate the test items with the closest degree of accuracy. When the impact of level of education on translation was discussed with ALL, she revealed that 'reasons' for translation also play a role in how translation is done, and this may not necessarily be related to level of education. Furthermore, she reported that translating items for a 'language assessment' may pose significant challenges for the translator and requires a higher level of precision than 'routine' translation. Therefore, despite the fact that in the South African context English is learned at school by the majority of the population and it can be argued that level of education may give a translator access to a greater vocabulary or to a greater degree of bilingualism, it may not necessarily improve their ability to make translations without changing the inherent meaning, especially in cases where the purpose of the translation has not been explicitly described.

\section{The role of multilingualism and language exposure on translation}

The number of languages that a translator is able to speak appears to play a role in the type of vocabulary that is used during translation. This was observed, for example, in the subtest of auditory verbal comprehension when the question, 'Are the lights on in this room?' was posed. Participants 1, 2 and 3 translated this sentence correctly. However, participants 4 and 5 substituted the isiZulu word 'ugesi' with the English word 'light'. This can possibly be explained by looking into where the participants are from. Participant 4 is from Newcastle in KwaZulu-Natal, where isiZulu is the dominant language, but many people from different backgrounds live there, and a number of languages are spoken. The same applies to participant 5 who is from Soweto. Therefore, it is understandable that they would not use the authentic isiZulu term, 'ugesi' for 'lights'. Nevertheless, it is unlikely that this translation would negatively influence the response elicited. The use of 'borrowed' English words during translation may also be related to age, in that the younger participants are more likely to have had more exposure to English as a result of being born during a time when more people were educated with English as a medium of instruction, and also having had more exposure to English on television.

\section{Conclusion}

Although this study employed a small sample size, it has effectively highlighted some of the potential dangers associated with non-formal and non-systematic use of informal translators in the translation of formal speech-language assessment tools. One may argue that the WAB is not the most frequently used assessment tool, yet the authors believe that similar results would have been obtained had another formal test been translated, given that the nature of the differences in translation were mostly related to vocabulary and semantics.

The findings suggested that test items may be affected by the language, culture, gender and level of education of the translator. This concurs with the findings of Mosdell et al. (2010); however, at this point these factors cannot be considered as definitive because of the preliminary nature of the study. These factors therefore warrant more in-depth attention in future studies where bigger sample sizes can be used.

While the effects that translation may have on the process of assessment of language impairments are undeniable, the solution to this is less clear. As SLTs we can continue to motivate for the employment of formal trained translators/interpreters, yet issues associated with the diversity of cultures and languages in the South African context may not be notably reduced in the presence of a translator. While the goal of employing a translator in cross-cultural consultations would be to reduce the effects of language barriers on the accurate assessment of speech and language impairments, this study produces evidence that mediated consultations may in fact be more complex in speech- 
language therapy than in general health communication, and warrant a different type of solution. Efforts to develop and standardise assessment tools in African languages, coupled with increasing the numbers of SLTs who speak African languages, need to be intensified as it appears these would be the most reliable and logical ways of ensuring that appropriate and effective SLT service delivery is achieved within this context.

Acknowledgement. The authors would like to thank Dr I J Mhlambi from the Department of African Languages, University of the Witwatersrand, for her active participation in the current study.

\section{References}

Anderson, N. B. (1992). Understanding cultural diversity. American Journal of Speech-Language Pathology, 1, 11-12. Berndt, R. S. (2001). Patterns of sentence comprehension in aphasia: A consideration of three hypotheses. Journal of Brain and Language, 60(2), 197-221.

Bornman, J, Sevcik, R. A., Romski, M., \& Pae, H. K. (2010). Successfully translating language and culture when adapting assessment measures. Journal of Policy and Practice in Intellectual Disabilities, 7, 111-118. doi:10.1111/ j.1741-1130.2010.00254.x

Davidson, B. (2001). Questions in cross-linguistic medical encounters: The role of the hospital interpreter. Anthropological Quarterly, 74(4), 170-178. doi:10.1353/anq.2001.0035

Department of Health (2011). Policy on language services (2011) for the National Department of Health. Retrieved from http://www.doh.gov.za/docs/policy/2011/15042011.pdf.

Elderkin-Thompson, V., Silver, R. C., \& Waitzkin, H. (2001).When nurses double as interpreters: A study of Spanishspeaking patients in a US primary care setting. Social Science and Medicine, 52(9), 1343-1358. doi:10.1016/ S0277-9536(00)00234-3

Ercikan, K. (1998). Translation effects in international assessments. International Journal of Educational Research, 29(4), 543-553. doi:10.1016/S0883-0355(98)00047-0

Flores, G., Laws, M. B., Mayo, S. J., Zuckerman, B., Abreu, M., Medina, L., \& Hardt E. J. (2003). Errors in medical interpretation and their potential clinical consequences in paediatric encounters. Paediatrics, 111(1), 6-15. doi:10.1542/peds.111.1.6

Foley, E. E. (2005). HIV/AIDS and African immigrant women in Philadelphia: Structural and cultural barriers to care. AIDS Care, 17(8), 1030-1043. doi:10.1080/09540120500100890

Friedland, D., \& Penn, C. (2003). Conversation analysis as a technique for exploring the dynamics of a mediated interview. International Journal of Communication Disorders, 38(1), 95-111. doi:10.1080/1368282030481
Geisinger, K. F. (1994). Cross-cultural normative assessment: Translation and adaptation issues influencing the normative interpretation of assessment instruments. Psychological Assessment, 6(4), 304-312. doi:10.1037//1040-3590.6.4.304

Gerber, B. (2009). A reflection on the development of a service-learning pedagogy for teaching and learning in speech-language therapy in South Africa. In M. Moore \& P. Lan Lin (Eds.), Service-learning in higher education paradigms and challenges (pp. 157-170). Indianapolis: University of Indianapolis Press.

Kennedy, M. R. T., \& Yorkston, K. M. (2000). Accuracy of metamemory after traumatic brain injury: Predictions during verbal learning. Journal of Speech, Language and Hearing Research, 43(5), 1072-1087.

Kertesz, A. (1982). The Western Aphasia Battery. New York: Grune \& Stratton.

Khoza K., Ramma L., Mophosho M., \& Moroka D. (2008). Digit speech reception threshold testing in Tswana/ English speakers. South African Journal of Communication Disorders, 55, 20-28.

Kuun, C., Zimu, V., Barnard, E., \& Davel, M. (2005). Statistical investigations into isiZulu intonation. Human Language Technologies Research, 1, 1-5.

Mochan, A., Modi, M., \& Modi, G. (2003). Stroke in black South African HIV-positive patients: A prospective analysis. Stroke - Journal of American Heart Association, 34, 10-15. doi: 10.1161/01.STR.0000043821.35051.FA

Mosdell, J., Balchin, R., \& Ameen, O. (2010). Adaptation of aphasia tests for neurocognitive screening in South Africa. South African Journal of Psychology, 40(3), 250-261.

Penn, C. (2007). Factors affecting the success of mediated medical interviews in South Africa. Current Allergy of Clinical Immunology, 20(2), 66-72.

Ovretveit, J. (1998). Making true comparisons. In I. Ovretveit (Ed.), Comparative and cross-cultural health research: A practical guide. Oxford: Radcliffe Medical Press. doi:10.1093/eurpub/8.1.87

South African Constitution. (1996). South African Bill of Rights. Retrieved from http://www.rebirth.co.za/bill of rights.SA1.htm 3 February 2011.

South African Medical Research Council. (2003). General principles including research in children, vulnerable groups, international collaboration and epidemiology. Retrieved from http://www.sahealthinfo.org/ethics/ ethicspolicy.htm 28 January 2011

Southern African Stroke Prevalence Initiative (SASPI) Project Team. (2004). Prevalence of stroke survivors in rural South Africa: results from the Southern Africa Stroke Prevalence Initiative. Stroke - Journal of the American Heart Association, 35, 627-632.

Spiggle, S. (1994). Analysis and interpretation of qualitative data in consumer research. The Journal of Consumer Research, 21(3): 491-503. doi:10.1086/209413

Statistics South Africa (2003). Prevalence of disability in South Africa. Retrieved from http://www.statssa.gov.za 23 February 2009.

Statistics South Africa (2010). Mid-year population estimates, 2010. Retrieved from http://www.statssa.gov.za/ publications/P0302/P03022010.pdf 21 January 2011.

Stolk, Y., Ziguras, S., Saunders, T., Garlick, R., Stuart, G., \& Coffey, G. (1998). Lowering the language barrier in an acute psychiatric setting. Australian and New Zealand Journal of Psychiatry, 32(3), 434-440. doi:10.3109/00048679809065538

Swedley, B. D., Stith, A. Y. \& Nelson, A. R. (2003). Unequal treatment: confronting racial and ethnic disparities Washington, DC: National Academies Press. doi:10.1016/S0003-4975(03)01205-0

Van Schoor, O., van Niekerk, J., \& Grobbelaar, B. (2001). Mechanical failures as a contributing cause of motor vehicle accidents: South Africa. Accident Analysis and Prevention, 33 (6), 713-721. doi:10.1016/S0001-4575(00)00083-X

\section{Table 2. Translation of the auditory verbal comprehension subtest of the WAB}

\begin{tabular}{|c|c|c|c|c|}
\hline WAB command & $\begin{array}{l}\text { Translation by translator } 1(\mathrm{KM}) \\
\text { and translator } 2(\mathrm{ALL})\end{array}$ & Participant & Zulu translation & English translation \\
\hline \multirow[t]{5}{*}{ Is your name Smith? } & 1: Igama lakho uSmith? & 1 & Igama lakho unguSmith na? & Is your name Smith? \\
\hline & \multirow{4}{*}{ 2: Igama lakho uSmith? } & 2 & Igama lakho uSmith? & Is your name Smith? \\
\hline & & 3 & Igama lakho uSmith? & Is your name Smith? \\
\hline & & 4 & Igama lakho uSmith na? & Is your name Smith? \\
\hline & & 5 & Igama lakho uSmith? & Is your name Smith? \\
\hline \multirow[t]{5}{*}{ Is your name Brown? } & 1: Igama lakho uBrown? & 1 & Uwu Mr Brown? & Is your name Brown? \\
\hline & \multirow{4}{*}{ 2: Igama lakho uBrown } & 2 & Igama lakho uBrown? & Is your name Brown? \\
\hline & & 3 & Igama lakho uBrown? & Is your name Brown? \\
\hline & & 4 & Igama lakho uBrown? & Is your name Brown? \\
\hline & & 5 & Igama lakho uBrown? & Is your name Brown? \\
\hline \multirow[t]{5}{*}{ Is your name (real name)? } & 1: Igama lakho u (real name)? & 1 & Igama lakho $\mathrm{u}(\underline{\text { real name }})$ na? & Is your name (real name)? \\
\hline & \multirow{4}{*}{ 2: Igama lakho u ( $\underline{\text { real name })}$ ? } & 2 & Igama lakho u( & Is your name (real name)? \\
\hline & & 3 & Igama lakho u(real name)? & Is your name (real name)? \\
\hline & & 4 & Igama lakho u(real name)? & Is your name (real name)? \\
\hline & & 5 & Igama lakho u(real name)? & Is your name (real name)? \\
\hline \multirow[t]{5}{*}{ Do you live in Toronto? } & 1: Uhlala Toronto? & 1 & Uhlala eToronto? & Do you live in Toronto? \\
\hline & \multirow[t]{4}{*}{ 2: Uhlala Toronto na? } & 2 & Uhlala eToronto? & Do you live in Toronto? \\
\hline & & 3 & Uhlala eToronto? & Do you live in Toronto? \\
\hline & & 4 & Uhlala eToronto na? & Do you live in Toronto? \\
\hline & & 5 & Uhlala eToronto? & Do you live in Toronto? \\
\hline \multirow[t]{5}{*}{ Do you live in Windsor? } & 1: Uhlala eWindsor? & 1 & Uhlala eWindsor? & Do you live in Windsor? \\
\hline & \multirow[t]{4}{*}{ 2: Uhlala eWindsor na? } & 2 & Uhlala eWindsor? & Do you live in Windsor? \\
\hline & & 3 & Uhlala eWindsor? & Do you live in Windsor? \\
\hline & & 4 & Uhlala eWindsor? & Do you live in Windsor? \\
\hline & & 5 & Uhlala eWindsor? & Do you live in Windsor? \\
\hline
\end{tabular}


Table 2. Translation of the auditory verbal comprehension subtest of the WAB (continued)

\begin{tabular}{|c|c|c|c|c|}
\hline WAB command & $\begin{array}{l}\text { Translation by translator } 1(\mathrm{KM}) \\
\text { and translator } 2(\mathrm{ALL})\end{array}$ & Participant & Zulu translation & English translation \\
\hline \multirow{5}{*}{$\begin{array}{l}\text { Are you a man or a } \\
\text { woman? }\end{array}$} & 1: Uyindoda noma umuntu wesifazane? & 1 & Umuntu wesilisa noma wesifazane? & Are you a male or female? \\
\hline & \multirow{4}{*}{ 2: Uyindoda noma umuntu wesifazane? } & 2 & Uyindoda noma umuntu wesifazane? & Are you a man or a woman? \\
\hline & & 3 & Uyinkosikazi noma indoda & Are you a woman or a man? \\
\hline & & 4 & $\begin{array}{l}\text { Ungumuntu wesifazane noma umuntu } \\
\text { wesilisa? }\end{array}$ & Are you a female or a male? \\
\hline & & 5 & Ingabe uyindoda noma umfazi? & $\begin{array}{l}\text { Could you be a man or a } \\
\text { woman? }\end{array}$ \\
\hline \multirow[t]{5}{*}{ Are you a doctor? } & 1: Ungudokotela? & 1 & Ungudokotela? & Are you a doctor? \\
\hline & \multirow{4}{*}{ 2: Ungudokotela na? } & 2 & Ungudokotela? & Are you a doctor? \\
\hline & & 3 & Uwudokotela yini? & Are you a doctor? \\
\hline & & 4 & Ungu-doctor & Are you a doctor? \\
\hline & & 5 & Igabe uwudokotela? & Could you be a doctor? \\
\hline \multirow[t]{5}{*}{ Am I a man or a woman? } & \multirow{2}{*}{$\begin{array}{l}\text { 1: Ngiwumuntu wesifazane noma } \\
\text { wesilisa? }\end{array}$} & 1 & Nguye umuntu wesifazane? & Is she the female here? \\
\hline & & 2 & Mina ngowesifazane? & Am I a woman? \\
\hline & \multirow{3}{*}{$\begin{array}{l}\text { 2: Ngiyindoda noma umuntu } \\
\text { wesifazane? }\end{array}$} & 3 & Lo, uyindoda noma wumuntu wesifazane? & Is she a male or female? \\
\hline & & 4 & Ungumuntu wesifazane noma wesilisa? & Are you a man or a woman? \\
\hline & & 5 & Ngigabe ngiyindoda noma umfazi? & Am I a man or a woman? \\
\hline \multirow{5}{*}{$\begin{array}{l}\text { Are the lights on in this } \\
\text { room? }\end{array}$} & 1: Ugesi uyakhanya yini la-endlini? & 1 & Kukhanyiswe la endlini? & Are the lights on in this room? \\
\hline & \multirow{4}{*}{ 2: Ugesi uyakhanya kulelikamelo na? } & 2 & Uyakhanya ugesi kuleligumbi? & Is the light on in this room? \\
\hline & & 3 & Kuyakhanya kulendlu noma akukhanyi? & $\begin{array}{l}\text { Are the lights on in this room } \\
\text { or not? }\end{array}$ \\
\hline & & 4 & I-light ikhanyisiwe kulendlu? & Are the lights on in this room? \\
\hline & & 5 & Ama-light ngabe ayakhanya kuleli-room? & Are the lights on in this room? \\
\hline \multirow[t]{5}{*}{ Is the door closed? } & 1: Umnyango uvaliwe? & 1 & Umnyango uvaliwe? & Is the door closed? \\
\hline & \multirow{4}{*}{ 2: Uvaliwe yini umnyango? } & 2 & Umnyango uvaliwe? & Is the door closed? \\
\hline & & 3 & Umnyango uvaliwe? & Is the door closed? \\
\hline & & 4 & Umnyango uvaliwe? & Is the door closed? \\
\hline & & 5 & Umnyango uvaliwe? & Is the door closed? \\
\hline \multirow[t]{5}{*}{ Is this a hotel? } & 1: Isehotela la? & 1 & Ihotela leli? & Is this a hotel? \\
\hline & \multirow[t]{4}{*}{ 2: Isehotela lapha? } & 2 & Ihotela leli? & Is this a hotel? \\
\hline & & 3 & Kusehotela la yini? & Is this a hotel? \\
\hline & & 4 & Ihotela leli? & Is this a hotel? \\
\hline & & 5 & Ihotela leli? & Is this a hotel? \\
\hline \multirow[t]{5}{*}{ Is this a therapy room? } & 1: I-therapy room yini le? & 1 & Indawo yokuhlolela le? & Is this an assessment room? \\
\hline & \multirow{4}{*}{ 2: Igumbi lokuhlolela leli? } & 2 & I-therapy room le? & Is this a therapy room? \\
\hline & & 3 & Kuse-therapy room yini la? & Is this a therapy room? \\
\hline & & 4 & Lena i-therapy room? & Is this a therapy room? \\
\hline & & 5 & Igabe igumbi lokongela leli? & $\begin{array}{l}\text { Could this be an assessment } \\
\text { room? }\end{array}$ \\
\hline \multirow{5}{*}{$\begin{array}{l}\text { Are you wearing red } \\
\text { pyjamas? }\end{array}$} & 1: Ugqoke amapyjama abomvu yini? & 1 & Ugqoke ama-pyjama abovu? & Are you wearing red pyjamas? \\
\hline & \multirow{4}{*}{$\begin{array}{l}\text { 2: Ugqoke izimpahla zokulala } \\
\text { ezibomvu? }\end{array}$} & 2 & Ugqoke ama-pyjama abovu na? & Are you wearing red pyjamas? \\
\hline & & 3 & Ugqoke ama-pyjama abovu yini? & Are you wearing red pyjamas? \\
\hline & & 4 & Ugqoke i-pyjama lokulala elibovu? & $\begin{array}{l}\text { Are you wearing sleeping } \\
\text { pyjamas that are red? }\end{array}$ \\
\hline & & 5 & Ugqoke ama-pyjama abovu? & Are you wearing red pyjamas? \\
\hline \multirow[t]{5}{*}{ Will paper burn in fire? } & 1: Iphpha lingasha emlilweni? & 1 & Iphepha lingasha emlilweni? & Can paper burn in fire? \\
\hline & \multirow{4}{*}{ 2: Iphepha lingasha yini emlilweni? } & 2 & Iphepha liyasha yini emlilweni? & Does paper burn in fire? \\
\hline & & 3 & Amaphepha ayasha yini emlilweni? & Can papers burn in fire? \\
\hline & & 4 & Iphepha liyavutha na? & Is paper burning? \\
\hline & & 5 & Igabe iphepha liyasha emlilweni? & Can paper burn in fire? \\
\hline
\end{tabular}




\section{Table 2. Translation of the auditory verbal comprehension subtest of the WAB (continued)}

\begin{tabular}{|c|c|c|c|c|}
\hline WAB command & $\begin{array}{l}\text { Translation by translator } 1(\mathrm{KM}) \\
\text { and translator } 2(\mathrm{ALL})\end{array}$ & Participant & Zulu translation & English translation \\
\hline \multirow[t]{5}{*}{$\begin{array}{l}\text { Does March come before } \\
\text { June? }\end{array}$} & $\begin{array}{l}\text { 1: Inynaga ka-March ifika kuqala kuneya- } \\
\text { June? }\end{array}$ & 1 & $\begin{array}{l}\text { Kuyenzeka lenyanga ka-March ifike } \\
\text { ngaphambi kwa-June? }\end{array}$ & $\begin{array}{l}\text { Does it happen that the month } \\
\text { of March comes before June? }\end{array}$ \\
\hline & \multirow{4}{*}{$\begin{array}{l}\text { 2: Inynaga ka-March ifika kuqala kuneya- } \\
\text { June? }\end{array}$} & 2 & U-March ufika ngaphambi kwa-June? & Does March come before June? \\
\hline & & 3 & $\begin{array}{l}\text { Yikuphi okuqamuka phambili, u-March } \\
\text { noma u-June? }\end{array}$ & $\begin{array}{l}\text { What comes first March or } \\
\text { June? }\end{array}$ \\
\hline & & 4 & $\begin{array}{l}\text { Inyanga ka-March ifika kuqala kuno-June } \\
\text { na? }\end{array}$ & $\begin{array}{l}\text { Does the month of March } \\
\text { come before June? }\end{array}$ \\
\hline & & 5 & Igabe u-March ufika before u-June? & $\begin{array}{l}\text { Could March come before } \\
\text { June? }\end{array}$ \\
\hline \multirow[t]{5}{*}{$\begin{array}{l}\text { Do you eat a banana before } \\
\text { you peel it? }\end{array}$} & $\begin{array}{l}\text { 1: Uyawuhluba kuqala yini ubanana } \\
\text { ngaphambi wokuthi uwudle? }\end{array}$ & 1 & Uyawudla ubanana ungakawuhlubi? & $\begin{array}{l}\text { Do you eat a banana before } \\
\text { you've peeled it? }\end{array}$ \\
\hline & \multirow[t]{4}{*}{$\begin{array}{l}\text { 2: Uyawuhluba kuqala yini ubanana } \\
\text { ngaphambi wokuthi uwudle? }\end{array}$} & 2 & Ubanana uwudla ungaka wuhlubi na? & $\begin{array}{l}\text { Do you eat a banana before you } \\
\text { peel it? }\end{array}$ \\
\hline & & 3 & Udla ubanana ngoba usuwuhlubile yini? & $\begin{array}{l}\text { Do you eat a banana because } \\
\text { you have peeled it? }\end{array}$ \\
\hline & & 4 & Udla ubanana kuqala before uwuhluba? & $\begin{array}{l}\text { Do you eat a banana first } \\
\text { before you peel it? }\end{array}$ \\
\hline & & 5 & $\begin{array}{l}\text { Igabe uyalidla ibanana ngaphambi } \\
\text { wokuthi ulihlubile? }\end{array}$ & $\begin{array}{l}\text { Can you eat a banana before } \\
\text { you peel it? }\end{array}$ \\
\hline \multirow[t]{5}{*}{ Does it snow in July? } & 1: Liyakhithika yini ngo-July? & 1 & Kuyenzeka likhithike ngo-July? & Can it snow in July? \\
\hline & \multirow{4}{*}{ 2: Liyakhithika yinii ngo-July? } & 2 & Liyakhithika ngo-July? & Does it snow in July? \\
\hline & & 3 & Kuyakhithika yini ngo-July? & Does it snow in July? \\
\hline & & 4 & Liyakhithika ngo-July? & Does it snow in July? \\
\hline & & 5 & Liyasnowa na ku-July? & Does it snow in July? \\
\hline \multirow[t]{5}{*}{ Is a horse larger than a dog? } & 1: Ihhashi likhulu kunenja? & 1 & Kuyenzeka ihhashi libel'khulu kunenja? & $\begin{array}{l}\text { Can a horse be bigger than a } \\
\text { dog? }\end{array}$ \\
\hline & 2: Ihhashi likhulu yini kunenja? & 2 & Ihhashi likhulu kunenja yini? & Is a horse bigger than a dog? \\
\hline & & 3 & Yini enkulu, inja noma ihhashi? & $\begin{array}{l}\text { What is larger, a dog or a } \\
\text { horse? }\end{array}$ \\
\hline & & 4 & Ihhashi likhulu kunenja yini? & Is a horse larger than a dog? \\
\hline & & 5 & Igabe ihhashi likhulu na kunenja? & Is a horse larger than a dog? \\
\hline \multirow[t]{5}{*}{$\begin{array}{l}\text { Do you cut the grass with } \\
\text { an axe? }\end{array}$} & 1: Uyabusika yini utshani ngembazo? & 1 & $\begin{array}{l}\text { Uyakwazi ukuthi ngembazo ugence } \\
\text { utshani? }\end{array}$ & Can you cut grass with an axe? \\
\hline & \multirow[t]{4}{*}{ 2: Uyabusika yini utshani ngembazo? } & 2 & Utshanii ubugunda ngembazo yini? & Do you cut grass with an axe? \\
\hline & & 3 & Uma usika utshani, usika ngembazo na? & $\begin{array}{l}\text { When you cut grass, do you } \\
\text { use an axe? }\end{array}$ \\
\hline & & 4 & Ugangamula utshani ngombese? & Can you cut grass with a knife? \\
\hline & & 5 & Igabe usika utshani ngembazo? & $\begin{array}{l}\text { Do you cut the grass with an } \\
\text { axe? }\end{array}$ \\
\hline
\end{tabular}


Table 3. Translation of the spontaneous speech subtest of the WAB

\begin{tabular}{|c|c|c|c|c|}
\hline WAB question & $\begin{array}{l}\text { Translation by translator } 1(\mathrm{KM}) \\
\text { and translator } 2(\mathrm{ALL})\end{array}$ & Participant & Zulu translation & English translation \\
\hline \multirow[t]{5}{*}{ How are you today? } & 1: Unjani namhlanje? & 1 & Unjani namhlanje? & How are you today? \\
\hline & \multirow{4}{*}{ 2: Unjani namhlanje? } & 2 & Unjani namhlanje? & How are you today? \\
\hline & & 3 & Unjani namhlanje? & How are you today? \\
\hline & & 4 & Unjani namhlanje? & How are you today? \\
\hline & & 5 & Unjani namhlanje? & How are you today? \\
\hline \multirow[t]{5}{*}{ Have you been here before? } & 1: Usuke weza lapha ngaphambilini? & 1 & Ukewaba-la? & Have you been here before? \\
\hline & \multirow{4}{*}{ 2: Usuke weza lapha ngaphambilini? } & 2 & Waka wafika-la phambili? & Have you been here before? \\
\hline & & 3 & Wakeweza-la ngelinye ilanga? & $\begin{array}{l}\text { Have you been here } \\
\text { previously? }\end{array}$ \\
\hline & & 4 & Ukewaba-la phambilini? & Have you been here before? \\
\hline & & 5 & Usuke waza la-phambilini? & Have you been here before? \\
\hline \multirow[t]{5}{*}{ What is your name? } & 1: Ubani igama lakho? & 1 & Igama lakho ungubani? & What is your name? \\
\hline & \multirow{4}{*}{ 2: Ubani igama lakho? } & 2 & Ubani igama lakho? & What is your name? \\
\hline & & 3 & Ubani igama lakho? & What is your name? \\
\hline & & 4 & Ubani igama lakho? & What is your name? \\
\hline & & 5 & Ubani igama lakho? & What is your name? \\
\hline \multirow[t]{5}{*}{ What is your address? } & 1: Lithini ikheli lakho? & 1 & Ikheli lakho lithini? & What is your address? \\
\hline & \multirow{4}{*}{ 2: Lithini ikheli lakho? } & 2 & Lithini ikheli lakho? & What is your address? \\
\hline & & 3 & Lithini ikheli lakho? & What is your address? \\
\hline & & 4 & Ithini i-address yakho? & What is your address? \\
\hline & & 5 & La ohlalakhona, i-address & $\begin{array}{l}\text { Where you stay, what is your } \\
\text { address? }\end{array}$ \\
\hline \multirow[t]{5}{*}{ What is your occupation? } & 1: Usebenza laphi? & 1 & Usebenza msebenzi muni? & What is your occupation? \\
\hline & \multirow[t]{4}{*}{ 2: Usebenza msebenzi muni? } & 2 & Usebenza kuphi? & Where do you work? \\
\hline & & 3 & Wenza msebenzi muni? & What is your occupation? \\
\hline & & 4 & Ilokunjana yakho.... Address? & $\begin{array}{l}\text { Participant thought } \\
\text { occupation was address, } \\
\text { therefore unable to translate } \\
\text { the question. }\end{array}$ \\
\hline & & 5 & Igabe uwenza msebenzi muni? & What is your occupation? \\
\hline \multirow[t]{5}{*}{$\begin{array}{l}\text { Tell me a little about why } \\
\text { you are here? }\end{array}$} & $\begin{array}{l}\text { 1: Ngitshele kabanzi ukuthi yini } \\
\text { ekubeka la-namhlanje. }\end{array}$ & 1 & $\begin{array}{l}\text { Awuthi ukungitshela fahla ukuthi } \\
\text { ubekwayini la. }\end{array}$ & $\begin{array}{l}\text { Tell me briefly why you are } \\
\text { here. }\end{array}$ \\
\hline & \multirow[t]{4}{*}{$\begin{array}{l}\text { 2: Ngitshele kabanzi ukuthi yini } \\
\text { ekubeka la-namhlanje. }\end{array}$} & 2 & Ongitshele kancane ukuthi ufunani la. & $\begin{array}{l}\text { Please tell me a little about } \\
\text { why you are here today. }\end{array}$ \\
\hline & & 3 & $\begin{array}{l}\text { Awungitshele ukuthi namhlanje } \\
\text { uzeleni la? }\end{array}$ & $\begin{array}{l}\text { Please can you please tell me } \\
\text { why you are here today? }\end{array}$ \\
\hline & & 4 & $\begin{array}{l}\text { Ngitshele kancane ukuthi yini uze-la } \\
\text { namhlanje. }\end{array}$ & $\begin{array}{l}\text { Tell me a little about why } \\
\text { you came here today. }\end{array}$ \\
\hline & & 5 & $\begin{array}{l}\text { Ngitshele kabanzi ukuthi yini ula- } \\
\text { namhlanje. }\end{array}$ & $\begin{array}{l}\text { Tell me a little why you are } \\
\text { here. }\end{array}$ \\
\hline
\end{tabular}




\section{Table 4. Translation of the sequential commands subtest of the WAB}

\begin{tabular}{|c|c|c|c|c|}
\hline WAB command & $\begin{array}{l}\text { Translation by translator } \\
1(K M) \text { and translator } 2(\mathrm{ALL})\end{array}$ & Participant & Zulu translation & English translation \\
\hline \multirow[t]{5}{*}{ Raise your hands } & 1: Phakamisa izandla zakho & 1 & Phakamisa isandla & Raise your hand \\
\hline & \multirow[t]{4}{*}{ 2: Phakamisa izandla zakho } & 2 & Ngicela uphakamise izandla & Please raise your hands \\
\hline & & 3 & Phakamisa izandla zakho & Raise your hands \\
\hline & & 4 & Phakamisa izandla zakho & Raise your hands \\
\hline & & 5 & Phakamisa isandla sakho & Raise your hand \\
\hline \multirow[t]{5}{*}{ Shut your eyes } & 1: Vala amehlo & 1 & Vala amehlo & Close your eyes \\
\hline & \multirow[t]{4}{*}{ 2: Chimeza } & 2 & Chimeza amehlo & Shut your eyes \\
\hline & & 3 & Vala amehlo akho & Close your eyes \\
\hline & & 4 & Vala amehlo & Close your eyes \\
\hline & & 5 & Vala amehlo akho & Close your eyes \\
\hline \multirow[t]{5}{*}{ Point to the chair } & 1: Khomba isitulo & 1 & Khomba isitulo/isihlalo & Point to the chair \\
\hline & \multirow[t]{4}{*}{ 2: Khimba isihlalo } & 2 & Khomba isitulo & Point to the chair \\
\hline & & 3 & Khomba isitulo & Point to the chair \\
\hline & & 4 & Khomba isitulo & Point to the chair \\
\hline & & 5 & Khomba isitulo & Point to the chair \\
\hline \multirow{5}{*}{$\begin{array}{l}\text { Point to the window, then to } \\
\text { the door }\end{array}$} & \multirow{2}{*}{$\begin{array}{l}\text { 1: Khomba ifasitela bese } \\
\text { ukhomba umnyango }\end{array}$} & 1 & Khomba efasteleni nase mnyango & Point to the window and the door \\
\hline & & 2 & $\begin{array}{l}\text { Khomba ifasitela mese ukhomba } \\
\text { umnyango }\end{array}$ & $\begin{array}{l}\text { Point to the window and then to } \\
\text { the door }\end{array}$ \\
\hline & \multirow{3}{*}{$\begin{array}{l}\text { 2: Khomba ifasitela bese } \\
\text { ukhomba umnyango }\end{array}$} & 3 & $\begin{array}{l}\text { Khomba ifasitela bese ukhomba } \\
\text { umnyango }\end{array}$ & $\begin{array}{l}\text { Point to the window and then to } \\
\text { the door }\end{array}$ \\
\hline & & 4 & Khomba ifasitela nomnyango & Point to the window and the door \\
\hline & & 5 & $\begin{array}{l}\text { Khomba ifasitela bese ukhomba } \\
\text { umnynago }\end{array}$ & $\begin{array}{l}\text { Point to the window and then point } \\
\text { to the door }\end{array}$ \\
\hline \multirow[t]{5}{*}{ Point to the pen and the book } & 1: Khomba ipeni nencwadi & 1 & Khomba ipeni nebuku & Point to the pen and the book \\
\hline & \multirow[t]{4}{*}{ 2: Khomba ipeni nencwadi } & 2 & Khomba ipeni nebuku & Point to the pen and the book \\
\hline & & 3 & $\begin{array}{l}\text { Khomba ibodwe bese ukhomba } \\
\text { ibuku }\end{array}$ & $\begin{array}{l}\text { Point to the pot and then to the } \\
\text { book }\end{array}$ \\
\hline & & 4 & Khomba i-ball peni nebuku & Point to the pen with the book \\
\hline & & 5 & $\begin{array}{l}\text { Khomba ipeni bese ukhomba } \\
\text { incwadi }\end{array}$ & $\begin{array}{l}\text { Point to the pen and then point to } \\
\text { the book }\end{array}$ \\
\hline \multirow[t]{5}{*}{ Point with the pen to the book } & 1: Ngepeni khomba incwadi & 1 & Khomba ngepeni ebukwini & Point with the pen to the book \\
\hline & \multirow[t]{4}{*}{ 2: Khomba ngepeni encwadini } & 2 & Khomba ibuku ngepeni & Point to the book with the pen \\
\hline & & 3 & Khomba incwadi ngepeni & Point to the book with the pen \\
\hline & & 4 & Khomba ikamu ne-ball peni & Point to the comb and the pen \\
\hline & & 5 & Khomba ngepeni encwadini & Point with the pen to the book \\
\hline \multirow[t]{5}{*}{ Point to the comb with the pen } & 1: Ngepeni khomba ikamu & 1 & Khomba ngepeni ekamini & Point with the pen to the comb \\
\hline & \multirow[t]{4}{*}{ 2: Khomba ikamu ngepeni } & 2 & Khomba ikamu ngepeni & Point to the comb with the pen \\
\hline & & 3 & Khomba ikamu ngepeni & Point to the comb with the pen \\
\hline & & 4 & Khomba ngepeni ekamini & Point with the pen to the comb \\
\hline & & 5 & Khomba ikamu ngepeni & Point to the comb with the pen \\
\hline \multirow{5}{*}{$\begin{array}{l}\text { With the book point to the } \\
\text { comb }\end{array}$} & 1: Ngencwadi, khomba ikamu & 1 & Ngencwadi, khomba ekamini & With the book point to the comb \\
\hline & \multirow[t]{4}{*}{ 2: Ngencwadi, khomba ikamu } & 2 & Khomba ikamu ngebuku & Point with the comb to the book \\
\hline & & 3 & Ngebuku khomba ikamu & With the book point to the comb \\
\hline & & 4 & Ebukwini pointa ibuku & On the book point to the book \\
\hline & & 5 & Ngencwadi, khomba ikamu & With the book point to the comb \\
\hline
\end{tabular}


Table 4. Translation of the sequential commands subtest of the WAB (continued)

\begin{tabular}{|c|c|c|c|c|}
\hline WAB command & $\begin{array}{l}\text { Translation by translator } 1(\mathrm{KM}) \\
\text { and translator } 2(\mathrm{ALL})\end{array}$ & Participant & Zulu translation & English translation \\
\hline \multirow[t]{5}{*}{$\begin{array}{l}\text { Put the pen on top of the book } \\
\text { then give it to me }\end{array}$} & $\begin{array}{l}\text { 1: Beka ipeni phezu kwencwadi } \\
\text { bese unikeza mina }\end{array}$ & 1 & $\begin{array}{l}\text { Awuthathe ipeni ulibeke phezu } \\
\text { ebukwini bese unikeza mina }\end{array}$ & $\begin{array}{l}\text { Take the pen and put it on top of the } \\
\text { book and give it to me }\end{array}$ \\
\hline & \multirow[t]{4}{*}{$\begin{array}{l}\text { 2: Beka ipeni phezu kwencwadi } \\
\text { bese unikeza mina }\end{array}$} & 2 & $\begin{array}{l}\text { Beka ipeni phezu kwebuku mese } \\
\text { uletha la-kimina }\end{array}$ & $\begin{array}{l}\text { Put the pen on top of the book and } \\
\text { then give it to me }\end{array}$ \\
\hline & & 3 & $\begin{array}{l}\text { Beka ipeni lakho phezu kwencwadi } \\
\text { bese unikeza mina }\end{array}$ & $\begin{array}{l}\text { Put your pen on top of the book and } \\
\text { then give it to me }\end{array}$ \\
\hline & & 4 & $\begin{array}{l}\text { Thatha i-ball peni ulibeke phezu } \\
\text { kwebuku mese unikeza mina }\end{array}$ & $\begin{array}{l}\text { Take the pen and put it on top of the } \\
\text { book and then give it to me }\end{array}$ \\
\hline & & 5 & $\begin{array}{l}\text { Beka ipeni phezu kwencadi bese } \\
\text { unikeza yena }\end{array}$ & $\begin{array}{l}\text { Put the pen on top of the book and } \\
\text { then give it to her }\end{array}$ \\
\hline \multirow[t]{5}{*}{$\begin{array}{l}\text { Put the comb on the other side } \\
\text { of the pen and turn over the } \\
\text { book }\end{array}$} & $\begin{array}{l}\text { 1: Beka ikamu ngale kwepeni bese } \\
\text { uphendula incwadi }\end{array}$ & 1 & $\begin{array}{l}\text { Thatha ikamu ulibeke enxenyeni } \\
\text { ethile kwincwadi bese uvala ibuku }\end{array}$ & $\begin{array}{l}\text { Take the comb and put it on the other } \\
\text { side of the book and then close the } \\
\text { book }\end{array}$ \\
\hline & \multirow[t]{4}{*}{$\begin{array}{l}\text { 2: Beka ikamu kuloluhlangothi } \\
\text { lwepeni bese uphendula incwadi }\end{array}$} & 2 & $\begin{array}{l}\text { Beka ikamu kulelelinye icela lepeni } \\
\text { mese uvala ibuku }\end{array}$ & $\begin{array}{l}\text { Put the comb on the other side of the } \\
\text { pen and then close the book }\end{array}$ \\
\hline & & 3 & $\begin{array}{l}\text { Beka ipeni ngalelinye icala bese } \\
\text { ulibeka phezu kwencwadi }\end{array}$ & $\begin{array}{l}\text { Put the pen on the other side and put it } \\
\text { on top of the book }\end{array}$ \\
\hline & & 4 & $\begin{array}{l}\text { Beka i-ball peni phezu kwekamu } \\
\text { bese ngiyayiphendula bese unikeza } \\
\text { mina }\end{array}$ & $\begin{array}{l}\text { Put the pen on top of the comb and } \\
\text { then I will turn it over and give it to me }\end{array}$ \\
\hline & & 5 & $\begin{array}{l}\text { Beka ikamu kuloluhlangothi } \\
\text { lwencwadi bese uphendula incwadi }\end{array}$ & $\begin{array}{l}\text { Put the comb on the other side of the } \\
\text { book and then turn over the book }\end{array}$ \\
\hline
\end{tabular}

